POLYMORPHONUCLEAR neutrophils (PMN) obtained from carrageenin-stimulated peritoneal cavities of rats, but not blood PMN, spontaneously produced nitric oxide (NO) when incubated in vitro. Incubation of the cells with the NO synthase inhibitors, L-imino-ethyl-L-ornithine ( $L$ NIO) or $N^{G}$-monomethyl-L-arginine (L-NMMA), inhibited NO production. This inhibition could be reversed by $\mathrm{L}$-arginine. Incubation of PMN with lipopolysaccharide (LPS) failed to enhance NO production. Pretreatment of the rats with dexamethasone (DEXA) prior to carrageenin injection or incubation of PMN with the glucocorticoid in vitro partially inhibited the spontaneous release of NO. On the other hand, when PMN obtained from DEXA pretreated rats were incubated in vitro with DEXA, NO synthase activity and hence NO generation were almost abolished. A similar inhibition was also observed following the addition of L-NIO or cycloheximide to cultures of carrageenin-elicited PMN. The NO production by PMN did not appear to be related to cell viability or apoptosis. Indeed, neither the blockade of NO generation by L-NIO nor the incubation of the neutrophils with a NO donor, $S$-nitroso-acetylpenicillamine (SNAP) modified the pattern of LDH release or DNA fragmentation. In summary, it appears that PMN migration triggers a continuous NO synthesis, and that NO produced by these cells is not related to their apoptosis.

Key words: Inflammation, Nitric oxide synthase, Programmed cell death.

\section{An increase in nitric oxide produced by rat peritoneal neutrophils is not involved in cell apoptosis}

\author{
I. M. Fierro, ${ }^{1}$ C. Barja-Fidalgo, ${ }^{1}$ R. M. Canedo, ${ }^{1}$ \\ F. Q. Cunha ${ }^{2, C A}$ and S. H. Ferreira ${ }^{2}$ \\ ${ }^{1}$ Department of Pharmacology, I.B., Universidade \\ do Estado do Rio de Janeiro; \\ ${ }^{2}$ Department of Pharmacology, Faculty of Medicine \\ of Ribeirão Preto, Universidade de São Paulo, \\ Avenida Bandeirantes, 3900, 14049-900 Ribeirão \\ Preto, Brazil \\ ${ }^{\mathrm{CA}}$ Corresponding Author
}

\section{Introduction}

Eukaryotic cells die either by necrosis caused by different kinds of injurious stimuli or by apoptosis, a process of self-destruction which is genetically programmed. This programmed cell death is a mechanism responsible for the removal of redundant cells during embryogenesis ${ }^{1}$ and organ involution, ${ }^{2}$ and seems to play a controlling role in counteracting cell proliferation. ${ }^{3}$ Ongoing apoptosis is characterized by specific alterations in the cell's morphology, including condensation of the nuclear chromatin. ${ }^{4}$ This event seems to result from the activation of an endogenous endonuclease which cleaves DNA into fragments that are multiples of $180-120 \mathrm{bp}^{5}$

Nitric oxide (NO) has been implicated in various physiological and pathological processes including cell injury and apoptosis., ${ }^{6,7} \mathrm{NO}$ is derived from the oxidation of the terminal guanidino nitrogen atom of L-arginine by the enzyme NO synthase (NOS), of which two general classes have been identified. Constitutive NO synthase
(cNOS) is a $\mathrm{Ca}^{2+} /$ calmodulin- and NADPHdependent enzyme, present in vascular endothelium, brain and platelets. ${ }^{8}$ The cNOS is mainly involved in physiological processes in the cardiovascular and nervous systems. ${ }^{9}$ Inducible NO synthase (iNOS) can be induced by LPS and cytokines in a large variety of cells including macrophages, hepatocytes, and vascular smooth muscle and endothelial cells. ${ }^{10}$ In contrast to cNOS, the activity of iNOS is $\mathrm{Ca}^{2+}$-independent and its induction is inhibited by glucocorticoids. ${ }^{11-13}$ The microbicidal and tumouricidal activities of macrophages are dependent on the generation of large amounts of NO resulting from the expression of iNOS in these cells. ${ }^{14,15}$

It has been shown that NO is involved in macrophage apoptosis. ${ }^{6,7}$ On the other hand, although neutrophils undergo extensive apoptosis at the inflammatory site, ${ }^{16}$ the role of NO in this process has not been addressed. Whereas NO production by macrophages is brought about only if the cells are stimulated with LPS and/or some cytokines, ${ }^{17}$ it has been reported that elicited neutrophils were able to produce 
NO spontaneously. ${ }^{18}$ This production was not enhanced by LPS or cytokines. ${ }^{19}$ It appears that the induction of NOS in neutrophils may be triggered by cell migration to the inflammatory site. $^{18,19}$ The properties of neutrophil NOS are still not well known, although it seems to be an unique enzyme. ${ }^{20}$ It is also unclear whether a turnover of NOS in vitro would be responsible for the continuous NO production by elicited neutrophils. ${ }^{11,18}$

In the present paper, we have studied the kinetics of NO production by carrageenin elicited-neutrophils, and we provide some evidence that a continuous turnover of NO synthase does occur in vitro. In addition, experiments were conducted to investigate the involvement of neutrophil-generated NO in the process of apoptosis of these cells.

\section{Materials and Methods}

Animals: Male albino Wistar rats, weighing between $150-200 \mathrm{~g}$, were maintained in temperature-controlled rooms at $23-25^{\circ} \mathrm{C}$, with free access to food and water.

Peritoneal polymorphonuclear neutrophil preparation: Rat peritoneal cavities were stimulated by the injection of carrageenin $(300 \mu \mathrm{g} /$ cavity $)$. Four and $12 \mathrm{~h}$ later, the peritoneal cells were harvested in phosphate buffered saline (PBS). The exudate cells were centrifuged $(200 \times \boldsymbol{g}, 10$ min) and resuspended in RPMI-1640 medium (Sigma, USA). In order to remove the macrophages, the cell suspension was allowed to adhere to plastic tissue culture dishes for $1 \mathrm{~h}$ at $37^{\circ} \mathrm{C}$ in a $\mathrm{CO}_{2}$ incubator. The erythrocytes present in the non-adherent cells were removed by hyposmotic lysis, and polymorphonuclear neutrophils (PMN) were resuspended at a final concentration of $5 \times 10^{6}$ cells $/ \mathrm{ml}$ of RPMI supplemented with $10 \%$ of fetal calf serum (FCS; Gibco, USA) and $100 \mathrm{U} / \mathrm{ml}$ of penicillin (Sigma, USA). The PMN content of the suspension was $95 \%$. The cell viability was assessed by their ability to exclude trypan blue dye. In some experiments, the animals were pretreated with dexamethasone (Sigma, USA; $1 \mathrm{mg} / \mathrm{kg}$, s.c.) $6 \mathrm{~h}$ and $30 \mathrm{~min}$ prior to, or together with, L-nitroarginine (Wellcome, UK; $30 \mathrm{mg} / \mathrm{kg}$, s.c.) $30 \mathrm{~min}$ before the administration of carrageenin.

Peripheral blood neutrophils: Rats were anaesthetized with ether and the blood collected by cardiac puncture in plastic syringes containing heparin. Leucocytes were isolated by dextran sedimentation, followed by hypotonic lysis. Blood PMN were resuspended at a final con- centration $10^{6}$ cells/ml RPMI supplemented with FCS and penicillin. The cell viability was assessed by the exclusion of trypan blue dye.

$P M N$ incubation in vitro: One $\mathrm{ml}$ aliquots of peritoneal or blood PMN suspended in RPMI medium were drawn into sterile Eppendorf tubes and incubated for $1 \mathrm{~h}$ to $72 \mathrm{~h}$ at $37^{\circ} \mathrm{C}$. In some experiments, the following drugs were added to the cell suspension at the beginning of the incubation: L-NMMA (Wellcome, UK; $200 \mu \mathrm{M}$ ), L-NIO (Wellcome, UK; $200 \mu \mathrm{M}$ ), L-arginine (Sigma, USA; $2 \mathrm{mM})$, dexamethasone $(10 \mu \mathrm{M})$, cycloheximide (Sigma, USA; $10 \mu \mathrm{M}$ ), LPS (lipopolysaccharide from Escherichia coli 0111.84, Sigma, USA; $1 \mu \mathrm{g} /$ $\mathrm{ml}$ ) or SNAP (Wellcome, UK; $1 \mathrm{mM}$ ). At selected times, the PMN suspensions were centrifuged $(2000 \times \boldsymbol{g}, 5 \mathrm{~min})$ and the supernatants stored at $-20^{\circ} \mathrm{C}$ until measurement of the nitrite content. In some experiments, the NOS activity of the cell pellet was also determined.

Nitrite assay: Nitrite levels were measured by the colorimetric assay based on the Griess reaction. ${ }^{21}$ Briefly, Griess reagent (1\% sulphanilamide, 0.1\% naphthylethylenediamine in 5\% phosphoric acid) was added to an equal volume of the supernatants and the absorbance at $546 \mathrm{~nm}$ measured after $10 \mathrm{~min}$. The nitrite $\left(\mathrm{NO}_{2}^{-}\right)$concentration was determined by reference to a standard curve of sodium nitrite.

NOS activity assay: At indicated times, PMN were sonicated in the extraction buffer $(320 \mathrm{mM}$ sucrose, $50 \mathrm{mM}$ TRIS, $1 \mathrm{mM}$ dithiotreitol, $10 \mu \mathrm{g} / \mathrm{ml}$ leupeptin, $10 \mu \mathrm{g} / \mathrm{ml}$ soybean trypsin inhibitor and $2 \mu \mathrm{g} / \mathrm{ml}$ aprotinin) and centrifuged $(10000 \times \boldsymbol{g})$ for $20 \mathrm{~min}$ at $4^{\circ} \mathrm{C}$. NOS activity in the supernatant was determined based on the conversion of $\mathrm{L}^{-}$ [U $\left.{ }^{14} \mathrm{C}\right]$ arginine $(20 \mu \mathrm{M})$ to $\mathrm{L}-\left[\mathrm{U}-{ }^{14} \mathrm{C}\right]$ citrulline following a 20 min incubation at $37^{\circ} \mathrm{C}$ as described previously. ${ }^{22}$ Unlabelled L-citrulline $(1 \mathrm{mM})$ and L-valine $(50 \mathrm{mM})$ were also added to the assay in order to inhibit arginase activity. ${ }^{22}$ The protein content of the supernatants was determined by the Coomassie blue binding method according to the manufacturer's recommendations (Pierce Chemical, Rockford, IL). Total NOS activity was expressed as pmol citrulline formed/ $\mathrm{mg}$ protein/min.

Measurement of lactate debydrogenase: The release of cytoplasmic lactate dehydrogenase (LDH) into the medium was used to evaluate PMN viability. The enzyme activity was measured by the assay based on the $\mathrm{LDH}$-induced reduction of pyruvate to lactate in the presence of $\mathrm{NADH}$, as described previously. ${ }^{23}$ Briefly, $0.1 \mathrm{ml}$ 
of fresh PMN supernatants obtained as described above (free of red blood cell contamination) were added to spectrophotometer cuvettes containing $2 \mathrm{mM}$ of $\mathrm{NADH}$ and $10 \mathrm{mM}$ of sodium pyruvate. The decrease in the absorbance at $340 \mathrm{~nm}$ was followed for 4 min (enzymatic rate of $\mathrm{LDH}$ ). Each sample was run in parallel with a positive control (cells disrupted with $0.2 \%$ digitonin) considered as $100 \%$ of death. LDH activity in PMN supernatants was expressed as a percentage of the positive control.

Apoptosis assays: After the indicated times, the PMN suspensions were centrifuged $(2000 \times \boldsymbol{g}, 5$ $\mathrm{min})$, the supernatants were removed and the pelleted cells were lysed with $0.5 \mathrm{ml}$ of lysing buffer $(0.2 \%$ Triton X-100, $10 \mathrm{mM}$ Tris and $1 \mathrm{mM}$ EDTA, $\mathrm{pH}$ 7.4). The tubes were then centrifuged for $10 \mathrm{~min}$ at $13000 \times \boldsymbol{g}$ and the supernatants were immediately separated. Half the volume was used for gel electrophoresis and the other half, as well as the pellet, was used for the diphenylamine (DPA) assay as described below.

Gel electrophoresis: The supernatant obtained as described above was treated with $0.3 \mathrm{ml} 5 \mathrm{M} \mathrm{NaCl}$ and isopropanol and left for $12 \mathrm{~h}$ at $-70^{\circ} \mathrm{C}$. DNA pellets were obtained by centrifugation $(13000 \times \mathbf{g}, 10 \mathrm{~min})$, washed twice with $70 \%$ ethanol, air dried, resuspended in $10 \mathrm{mM}$ Tris, $1 \mathrm{mM}$ EDTA $(\mathrm{pH} 7.4)$ and incubated at $37^{\circ} \mathrm{C}$ for $10 \mathrm{~min}$. A loading buffer (20\% Ficoll 400, $0.1 \mathrm{M}$ EDTA, 1\% SDS, O.25\% bromophenol blue) was added at a final proportion of 10:1 and the samples were electrophoresed on $1 \%$ agarose gel containing $1 \mu \mathrm{g}$ of ethidium bromide $/ \mathrm{ml}$. The DNA bands were visualized and photographed under UV illumination.

$D P A$ reaction: Two hundred and fifty $\mu$ lof trichloroacetic acid (TCA, 25\%) were added to the pellet containing uncut DNA and to the other half of the supernatant containing DNA fragments. The tubes were incubated overnight at $4^{\circ} \mathrm{C}$ and the precipitated DNA was pelleted by centrifugation $(10 \mathrm{~min}, 13000 \times \mathbf{g})$. Eighty $\mu$ l of a 5\% TCA solution was added to each pellet and DNA was hydrolysed by heating for $15 \mathrm{~min}$ at $90^{\circ} \mathrm{C}$. One hundred and sixty $\mu \mathrm{l}$ of a freshly preparated DPA reagent $(150 \mathrm{mg}$ DPA, $10 \mathrm{ml}$ glacial acetic acid, $0.15 \mathrm{ml}$ concentrated sulfuric acid, $0.05 \mathrm{ml} 1.6 \%$ acetaldehyde solution) were then added to the tubes and the colour was allowed to develop for $4 \mathrm{~h}$ at $37^{\circ} \mathrm{C}$. The reaction was quantitated spectrophotometrically at $570 \mathrm{~nm}$. The percentage of fragmented DNA was calculated using the formula

$$
\% \text { fragmented DNA }=\frac{\mathrm{OD}(\mathrm{SN})}{\mathrm{OD}(\mathrm{SN})+\mathrm{OD}(\mathrm{pellet})} \times 100
$$

where $\mathrm{SN}$ is the supernatant and $\mathrm{OD}$ is the optical density.

Statistical analysis: Statistical significance was assessed by ANOVA followed by the Bonferroni $t$ test and $p<0.05$ was taken as statistically significant.

\section{Results}

Production of $\mathrm{NO}_{2}^{-}$by rat peritoneal PMN: Neutrophils harvested from rat peritoneal cavities stimulated with carrageenin spontaneously release $\mathrm{NO}_{2}^{-}$when incubated in vitro. The levels of $\mathrm{NO}_{2}^{-}$in the medium were already detectable after $1 \mathrm{~h}$ of incubation and increased continuously over $24 \mathrm{~h}$. The cells harvested from peritoneal cavities $12 \mathrm{~h}$ after the carrageenin injection released about 4-fold more $\mathrm{NO}_{2}^{-}$than those obtained $4 \mathrm{~h}$ post-injection (Fig. 1(A)). The addition of LPS $(1 \mu \mathrm{g} / \mathrm{ml})$ to the PMN suspension did not modify the pattern of $\mathrm{NO}_{2}^{-}$accumulation in the supernatants. Fig. 1 (B) shows that $\mathrm{NO}_{2}^{-}$ generation by PMN was abolished by the presence of $200 \mu \mathrm{M}$ L-NIO (the $\mathrm{NO}_{2}$ concentration was equivalent to that measured in the culture medium) and was partially inhibited by L-NMMA at the same concentration. The L-NMMA effect was completely reversed by L-arginine ( $2 \mathrm{mM})$.

Production of $\mathrm{NO}_{2}^{-}$by rat peritoneal blood $P M N$ : In contrast to peritoneal neutrophils, blood PMN collected from untreated or carrageenin-stimulated rats, did not produce significant amounts of $\mathrm{NO}_{2}^{-}$, after a $24 \mathrm{~h}$ incubation in vitro, spontaneously or even after stimulation with LPS $(10 \mu \mathrm{g} / \mathrm{ml})$ in vitro. Results for untreated rats were $1.5 \pm 1.4 \mu \mathrm{M}$ (controls) and $2.3 \pm 2.0 \mu \mathrm{M}$ (LPS stimulated PMN); while results for carrageenin treated rats were $2.9 \pm 2.2 \mu \mathrm{M}$ (controls) and $6.5 \pm 4.7 \mu \mathrm{M}$ of $\mathrm{NO}_{2}$ (LPS stimulated PMN).

Effect of dexamethasone, L-NIO, and cyclobeximide on $\mathrm{NO}_{2}^{-}$production and NOS activity of peritoneal neutrophils: Fig. 2 shows that the pretreatment of the rats with dexamethasone prior to carrageenin injection partially inhibited the spontaneous release of $\mathrm{NO}_{2}^{-}$by peritoneal neutrophils. A similar inhibition was obtained when neutrophils were treated in vitro with dexamethasone. However, the addition of dexamethasone $(10 \mu \mathrm{M})$ in vitro to PMN obtained from dexamethasone-pretreated rats strongly inhibited $\mathrm{NO}_{2}^{-}$generation. The same effect was 


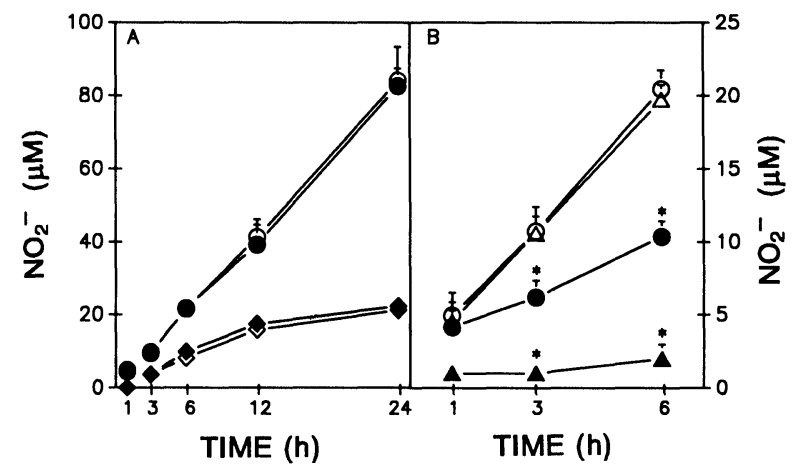

FIG. 1. (A) The time course and effect of LPS $(1 \mu \mathrm{g} / \mathrm{ml}$; filled symbols) on $\mathrm{NO}_{2}^{-}$generation by cultured rat PMN harvested from the peritoneal cavity $4 \mathrm{~h}(\diamond)$ and $12 \mathrm{~h}(\bullet)$ after carrageenin $(\mathrm{Cg})$ stimulation. The open symbols represent the response in the absence of LPS. (B) The inhibitory effect of $200 \mu \mathrm{M} L-$ NMMA $(\mathbf{O})$ and $200 \mu \mathrm{M}$ L-NIO (A) on $\mathrm{NO}_{2}^{-}$generation by PMN harvested $12 \mathrm{~h}$ after $\mathrm{Cg}$. L-Arginine $(2 \mathrm{mM}, \triangle)$ reversed the inhibitory effect of L-NMMA. The open circle represents the response in the absence of NOS inhibitor. Each point is the mean \pm S.D. $(n=5) . " p<0.05$ compared to non-treated group (ANOVA, followed by Bonferroni's $t$ test).

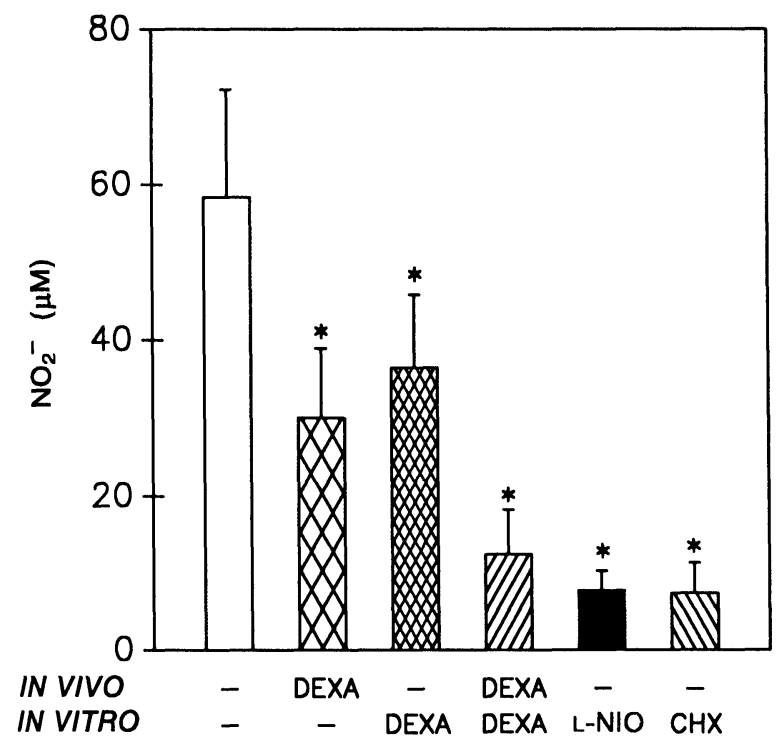

FIG. 2. The in vitro effect of dexamethasone (DEXA, 10 $\mu \mathrm{M}$ ), LNIO $(200 \mu \mathrm{M})$ and cycloheximide $(\mathrm{CHX}, 10 \mu \mathrm{M})$ on $\mathrm{NO}_{2}^{-}$generation by PMN harvested from the Cg-injected peritoneal cavity of untreated $(-)$ rats or from animals pretreated with DEXA $11 \mathrm{mg} /$ $\mathrm{kg}$ ). The cells were harvested from rats injected $12 \mathrm{~h}$ previously with carrageenin and were incubated for $24 \mathrm{~h}$ in vitro. The bars represent the mean \pm S.D. $(n=5) . " p<0.05$ compared to nontreated group (ANOVA followed by Bonferroni's $t$ test).

observed when L-NIO $(200 \mu \mathrm{M})$ and cycloheximide $(10 \mu \mathrm{M})$ were incubated in vitro with neutrophils obtained from untreated rats.

In agreement with these results, the NOS activity assayed in neutrophils treated in vitro or in vivo with dexamethasone was inhibited when compared with control cells: control, $2.30 \pm 0.30$; dexamethasone in vivo, $0.78 \pm 0.08$ and dexamethasone in vitro, $0.46 \pm 0.05 \mathrm{pmol}$ of citrulline formed $/ \mathrm{min} / \mathrm{mg}$ protein.
Release of $L D H$ and DNA fragmentation: Table I shows that there was no correlation between the levels of NO generated and the release of $\mathrm{LDH}$ by rat peritoneal PMN incubated for $24 \mathrm{~h}$ in vitro. The incubation of neutrophils obtained from untreated or nitro-arginine-pretreated rats with L-NIO blocked $\mathrm{NO}_{2}^{-}$production but did not change the amount of $\mathrm{LDH}$ released. The same result was obtained when PMN were treated in vitro with dexamethasone. In addition, SNAP, an NO donor, even at a high concentration $(1 \mathrm{mM})$, did not affect the LDH release. Smaller doses of SNAP $(0.1$ and $0.3 \mathrm{mM})$ also did not affect the LDH release.

The analysis of DNA fragmentation in PMN harvested $4 \mathrm{~h}$ after carrageenin injection (Fig. 3(A)), showed only 1 to $4 \%$ of fragmented DNA. When these cells were incubated for $24 \mathrm{~h}$ in vitro, in the presence or in the absence of $\mathrm{L}-$ NIO or SNAP, the percentage of segmented DNA increased to $23 \%$. The same pattern of DNA fragmentation was also seen with PMN obtained from animals pretreated in vivo with dexamethasone (not shown in the figure). On the other hand, this percentage of fragmentation rose to about $60 \%$ when dexamethasone was added to the medium. Blood PMN, when incubated in vitro for $24 \mathrm{~h}$, showed a similar pattern of DNA fragmentation $\left(\mathrm{t}_{0}=8 \pm 2.4 \% ; \mathrm{t}_{24}=29.4 \pm 8.8 \%\right)$, although it did not produce NO.

The gel electrophoresis of DNA extracted from neutrophils incubated for $24 \mathrm{~h}$ (Fig. 3(B), Lane 3) showed, in contrast with non-incubated cells (Lane 2), the internucleosomal fragmentation pattern typical of endonuclease activation and apoptosis. The characteristic DNA ladder with 180-bp steps did not change, even when NO generation was inhibited by L-NIO or dexamethasone (Lanes 4 and 6). The addition of SNAP, an NO donor, at a dose of $1 \mathrm{mM}$, also did not change the pattern of DNA fragmentation (Lane 5). Smaller doses of SNAP (0.1 and $0.3 \mathrm{mM}$ ) gave similar results. As with $\mathrm{LDH}$ release, the index of DNA fragmentation was not altered in neutrophils obtained from rats pretreated with nitro-arginine and incubated in vitro for $24 \mathrm{~h}$ in the presence or absence of L-NIO.

\section{Discussion}

In the present investigation, we have shown that neutrophils obtained 4 and $12 \mathrm{~h}$ after i.p. injection of carrageenin continuously and spontaneously produced $\mathrm{NO}_{2}^{-}$when incubated in vitro. This production was partially inhibited by $\mathrm{L}$ NMMA or abolished by L-NIO. This inhibition could be reversed by L-arginine. These results clearly indicate that $\mathrm{NO}_{2}^{-}$measured by the Griess 
Table 1. Generation of $\mathrm{NO}_{2}^{-}$and $\mathrm{LDH}$ release (\% total) by rat peritoneal $\mathrm{PMN}$ incubated for $24 \mathrm{~h}$ in vitro

\begin{tabular}{|c|c|c|c|c|}
\hline \multirow[t]{2}{*}{ Treatment } & \multicolumn{2}{|c|}{$\mathrm{LDH}(\%) \pm$ S.D. } & \multicolumn{2}{|c|}{$\mathrm{NO}_{2}(\mu \mathrm{M}) \pm$ S.D. } \\
\hline & $\mathrm{Cg}, 4 \mathrm{~h}$ & $\mathrm{Cg}, 12 \mathrm{~h}$ & $\mathrm{Cg}, 4 \mathrm{~h}$ & $\mathrm{Cg}, 12 \mathrm{~h}$ \\
\hline $\begin{array}{l}\text { Control } \\
\text { (Cg, i.p.) }\end{array}$ & $18.2 \pm 3.0$ & $36.0 \pm 2.0$ & $23.4 \pm 1.9$ & $87.5 \pm 6.0$ \\
\hline $\begin{array}{l}\text { Nitro-arg in vivo } \\
(30 \mathrm{mg} / \mathrm{kg})\end{array}$ & $24.8 \pm 3.1$ & $35.0 \pm 7.0$ & $22.7 \pm 1.7$ & $89.7 \pm 2.4$ \\
\hline $\begin{array}{l}\text { L-NIO in vitro } \\
(200 \mu \mathrm{M})\end{array}$ & $22.6 \pm 1.71$ & $29.0 \pm 2.2$ & $3.90 \pm 1.0^{*}$ & $7.70 \pm 2.6^{*}$ \\
\hline $\begin{array}{l}\text { Nitro-arg in vivo }+ \\
\text { L-NIO in vitro }\end{array}$ & $16.8 \pm 6.0$ & $35.0 \pm 6.2$ & $4.11 \pm 1.2^{*}$ & $3.67 \pm 2.8^{*}$ \\
\hline $\begin{array}{l}\text { Dexamethasone in } \\
\text { vitro }(10 \mu \mathrm{M})\end{array}$ & $23.6 \pm 2.7$ & $33.82 \pm 1.6$ & $12.8 \pm 2.7^{*}$ & $41.7 \pm 4.8^{*}$ \\
\hline $\begin{array}{l}\text { SNAP in vitro } \\
(1 \mathrm{mM})\end{array}$ & $24.2 \pm 6.5$ & $32.3 \pm 3.8$ & ND & ND \\
\hline
\end{tabular}

ND: not determined. ${ }^{*} p<0.05$ compared to control values (ANOVA followed by Bonferroni's $t$ test).

method resulted from the oxidation of NO generated through the activity of the NOS present in neutrophils. It must be pointed out, however, that circulating neutrophils obtained from either untreated or carrageenin-stimulated rats did not synthesize NO in identical in vitro experimental conditions. These data support the idea ${ }^{18}$ that the passage of neutrophils to the inflammatory site may be the mechanism responsible for the triggering of NOS activity. Cytokines produced at the onset of the inflammatory response may perhaps activate NOS in PMN which will then produce NO once they arrive at the inflammatory site. This suggestion is supported by the findings that NOS activity in PMN obtained from animals pretreated with dexamethasone, which has a known inhibitory effect on cytokine production ${ }^{24}$ and on NOS induction, was partially but significantly inhibited. Furthermore, it appears that in the PMN the threshold level for NOS induction reaches its maximum in peritoneal cavities, since LPS at doses which usually stimulate iNOS in other cells, particularly in macrophages ${ }^{16}$ failed to further stimulate NOS in these PMN. The observations that cycloheximide, a protein synthesis inhibitor, blocked NO production in vitro, and that dexamethasone also partially inhibited the NO production in vitro, suggest that NO generation by elicited $\mathrm{PMN}$ in vitro also requires a continuous synthesis of NOS. These findings are in line with previous data, ${ }^{11}$ but contrast with the absence of an affect of cycloheximide on the spontaneous release of $\mathrm{NO}_{2}^{-}$by neutrophils obtained from rat peritoneal cavities challenged with oyster glycogen. ${ }^{19}$ The activation of iNOS was further confirmed by the observation that the combined in vivo and in vitro treatment with dexamethasone almost abolished $\mathrm{NO}_{2}^{-}$production and NOS activity, the latter measured by the citrulline assay.

Recently, it was shown that NO production appears to be associated with macrophage programmed cell death. ${ }^{6,7}$ Our results indicate that in neutrophils there was no correlation between the loss of cell viability (as assessed by LDH release) or DNA fragmentation (an indicator of apoptosis) and NO production. This was shown in experiments in which L-NIO, at a concentration that abolished NO generation, or SNAP, a NO donor used at an effective microbicidal concentration, ${ }^{25}$ failed to change the pattern of DNA fragmentation or of $\mathrm{LDH}$ release observed for neutrophils incubated for $24 \mathrm{~h}$. In some experiments, the effects of endogenous NO were avoided by pretreating the animals with L-nitroarginine and the peritoneal cells were incubated in vitro with L-NIO. Although these treatments completely prevented NO generation, the pattern of DNA fragmentation or $\mathrm{LDH}$ release did not change. In agreement, non-stimulated blood neutrophils which did not release NO, also underwent apoptosis after $24 \mathrm{~h}$ of incubation in vitro. Moreover, pretreatment of the rats with dexamethasone, which was shown to inhibit the induction of NOS in vivo, did not decrease DNA fragmentation observed after $24 \mathrm{~h}$ of PMN incubation (data not shown). On the other hand, when dexamethasone was added in vitro to PMN suspensions an enhancement of apoptosis occurred, an effect already observed for thymocytes ${ }^{26}$ and $\mathrm{T}$ cell leukaemia lines. ${ }^{27}$ This effect of dexamethasone is probably not related to its action in inhibiting NOS. Taken together, our data indicate that NO produced by rat peritoneal neutrophils 

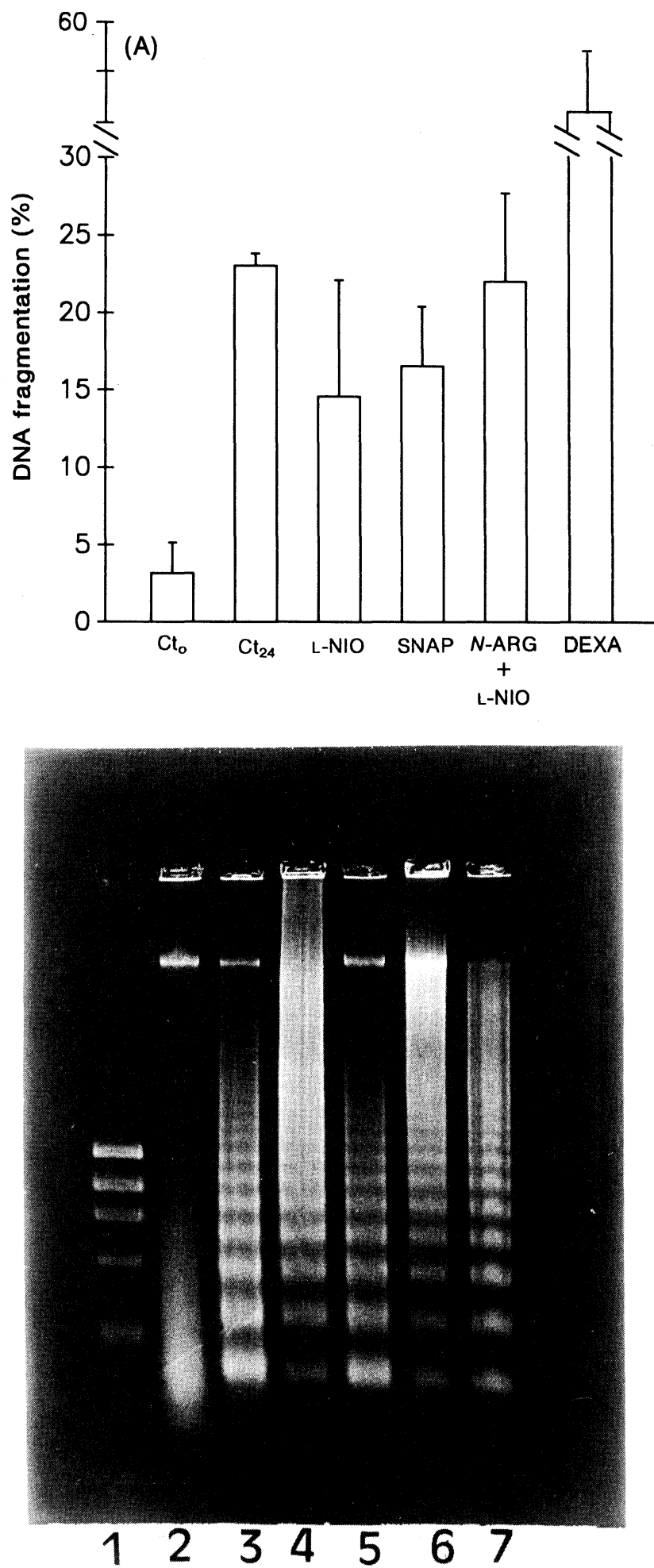

FIG. 3. (A) The in vitro effect of different treatments on DNA fragmentation. PMN were cultured for $24 \mathrm{~h}$ with the indicated reagents: RPMI $\left(\mathrm{Ct}_{24}\right) \mathrm{L}$-NIO $(200 \mu \mathrm{M})$, SNAP $(1 \mathrm{mM})$, and dexamethasone (DEXA, $10 \mu \mathrm{M})$. PMN from rats pretreated with L-nitroarginine $(30 \mathrm{mg} / \mathrm{kg})$ were also cultured with L-NIO $(200 \mu \mathrm{M}$; $\mathrm{N}$-Arg+L-NIO). The percent of DNA fragmentation was assayed by the DPA method. The first bar $\left(\mathrm{Ct}_{0}\right)$ shows the percentage of DNA fragmentation of the non-incubated PMN. The data are the mean \pm S.D. of five determinations from a representative experiment. (B) Gel electrophoresis of DNA isolated from PMN before any incubation (Lane 2) and from PMN cultured for $24 \mathrm{~h}$ without (Lane 3) or with L-NIO, SNAP or dexamethasone (Lanes 4-6, respectively). The first lane shows the molecular weight markers. is not involved in the apoptosis of these cells in vitro. Further investigation is required in order to establish which mediators are involved in this process.

In summary, we have shown here that PMN migration to the inflammatory site probably triggers NOS induction and that NO generation at the inflammatory site is not associated with the phenomenon of apoptosis in these cells.

\section{References}

1. Oppenheim RW. Naturally occurring cell death during neural develop ment. Trends Neurosci 1985; 8: 487-493.

2. Wyllie AH, Kerr JFR, Currie AR. Cell death: the significance of apoptosis Int Rev Cytol 1980; 68: 251-306.

3. Wyllie $\mathrm{AH}$. Apoptosis and the regulation of cell numbers in normal and neoplastic tissues: an overview. Cancer and Metast Rev 1992; 11: 95103.

4. Kerr IFR, Wyllie AH, Currie AR. Apoptosis: a basic biological phenom enon with wide-ranging implications in tissue kinetics. Br J Cancer 1972; 26: 239-257.

5. Arends MJ, Morris RG, Wyllie AH. Apoptosis, the role of the endonuclease. Am J Patbol 1990; 136: 593-608.

6. Sarih M, Souvannavong V, Adam A. Nitric oxide synthase induces macrophage death by apoptosis. Biochem Biophys Res Commun 1993; 191: $503-508$

7. Albina JE, Cui S, Mateo RB, Reichner JS. Nitric oxide-mediated apoptosis in murine peritoneal macrophages. J Immunol 1993; 150: 5080-5085.

8. Moncada S, Palmer RMJ, Higgs EA. Nitric oxide: physiology, pathophysioogy and pharmacology. Pharmacol Rev 1991; 43: 109-142.

9. Moncada S, Higgs EA. Endogenous nitric oxide: physiology, pathology and clinical relevance. Eur J Clin Invest 1991; 21: 361-374.

10. Hibbs JB, Taintor RR, Vavrin Z, et al. Synthesis of nitric oxide from a terminal guanidino atom of $\mathrm{L}$-arginine: a molecular mechanism regulating cellular proliferation that targets intracellular iron. In: Moncada $S$ and Higgs EA, eds. Nitric Oxide from L-Arginine: a Bioregulatory System Amsterdam: Elsevier (Excerpta Medica), 1990; 189-195.

11. McCall TB, Palmer RMJ, Moncada S. Induction of nitric oxide synthase in rat peritoneal neutrophils and its inhibition by dexamethasone. Eur $J$ Immunol 1991; 21: 2523-2527.

12. Radomski MW, Palmer RMJ, Moncada S. Glucocorticoids inhibit the expression of an inducible, but not the constitutive, nitric oxide synthase in vascular endothelial cells. Proc Natl Acad Sci USA 1990; 87: 1004310047.

13. Ialenti A, Ianaro A, Moncada S, Di Rosa M. Modulation of acute inflammation by endogenous nitric oxide. Eur J Pharmacol 1992; 211: 177-182.

14. Cunha FQ, Assreuy J, Xu D, Charles I, Liew FY, Moncada S. Repeated induction of nitric oxide synthase and leishmanicidal activity in murine macrophages. Eur I Immunol 1993; 23: 1385-1388.

15. Cunha FQ, Assreuy J, Moss DW, et al. Differential induction of nitric oxide synthase in various organs of the mouse during endotoxaemia role of TNF-alpha and IL-1-beta. Immunology 1994; 81: 211-215.

16. Savill JS, Wyllie AH, Henson JE, Walport MJ, Henson PM, Hasllet C. Macrophage phagocytosis of aging neutrophils in inflammation. Programmed cell death in the neutrophil leads to its recognition by macrophages. $J$ Clin Invest 1989; 83: 865-875.

17. Stuehr DJ, Gross S, Sakuma I, Levi R, Nathan CF. Activated murine macrophages secrete a metabolite of arginine with the bioactivity of EDRF and the chemical reactivity of NO. J Exp Med 1989; 169: 1011-1020.

18. McCall TB, Boughton-Smith N, Palmer RMJ, Whittle BJR, Moncada S Synthesis of nitric oxide from L-arginine by neutrophils. Biochem J 1989: 261: $293-296$

19. Stewart AG, Dusting GJ, Giarracca RG, Harris T, Lim Y, Sobey CG. Nitrite is produced by elicited but not by circulating neutrophils. Mediat Inflam mat 1993; 2: 349-356.

20. Hiki K, Yui Y, Hattori R, Eizawa H, Kosuga K, Kawai C. Three regulation mechanisms of nitric oxide synthase. Eur J Pharmacol 1991; 206: 163 164

21. Green LC, Wagner DA, Glogowski J, Skipper PL, Wishnok JS, Tannen baum SR. Analysis of nitrate, nitrite and $\left[{ }^{15} \mathrm{~N}\right]$ nitrate in biological fluids. Anal Biochem 1982; 126: 131-138.

22. Salter M, Knowles RG, Moncada S. Widespread tissue distribution, specie distribution and changes in activity of $\mathrm{Ca}^{2+}$-dependent and $\mathrm{Ca}^{2+}$-independent nitric oxide synthases. FEBS Lett 1991; 291: 145-150.

23. Johansen KS, Berger EM, Repine JE. Effect of temperature on poly morphonuclear leukocyte functions. Acta Path Microbiol Immunol Scand 1983; 91: 355-359.

24. Munck A, Mendel DB, Smith LI, Orti E. Glucocorticoid receptors and actions. Am Rev Resp Dis 1990; 141: S2-S10.

25. Assreuy J, Cunha FQ, Epperlein M, et al. Production of nitric oxide and 
superoxide by activated macrophages and killing of Leishmania major Eur J Immunol 1994; 24: 672-676.

26. Cohen JJ, Duke RC. Glucocorticoid activation of a calcium-dependent endonuclease in thymocyte nuclei leads to cell death. I Immunol 1984; 132: $38-42$.

27. Bansal N, Houle A, Melnykovych G. Apoptosis: mode of cell death induced in $\mathrm{T}$ cell leukemia lines by dexamethasone and other agents. FASEB J 1991; 5: 211-216.

ACKNOWLEDGMENTS. The authors thank Neomesia Issajoara Freiri and Fabiola Mestriner for their excellent technical assistance and Milton Ozório Morais for his expertise in standardizing the procedure for DNA gel electrophoresis. I. Fierro was supported by a fellowship from CNPq (Conselho Nacional de Pesquisa Científica). This work was supported by FAPESP, CNPq (Brazil) and IFS (Sweden).

\section{Received 21 February 1995;}

accepted in revised form 27 March 1995 


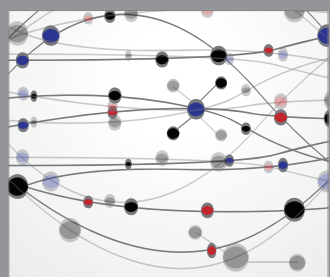

The Scientific World Journal
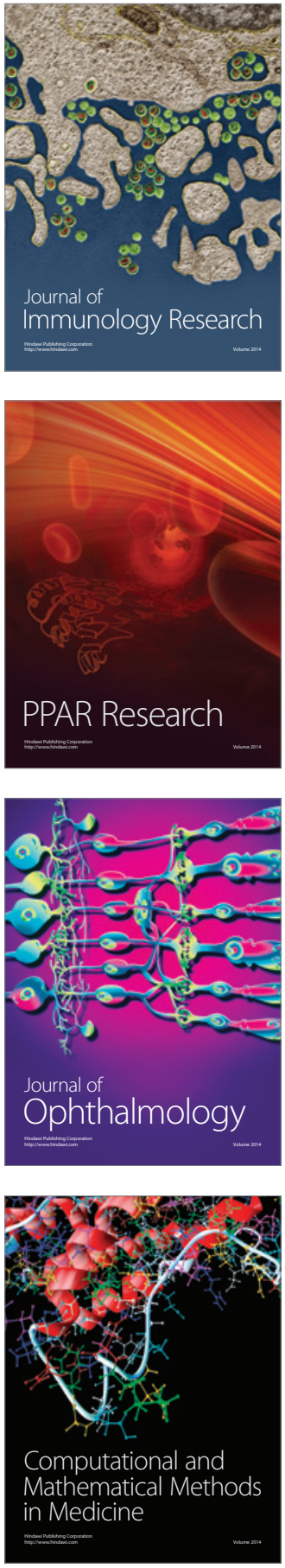

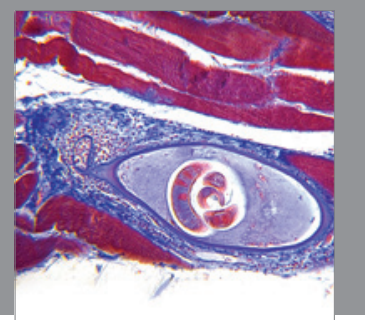

Gastroenterology

Research and Practice
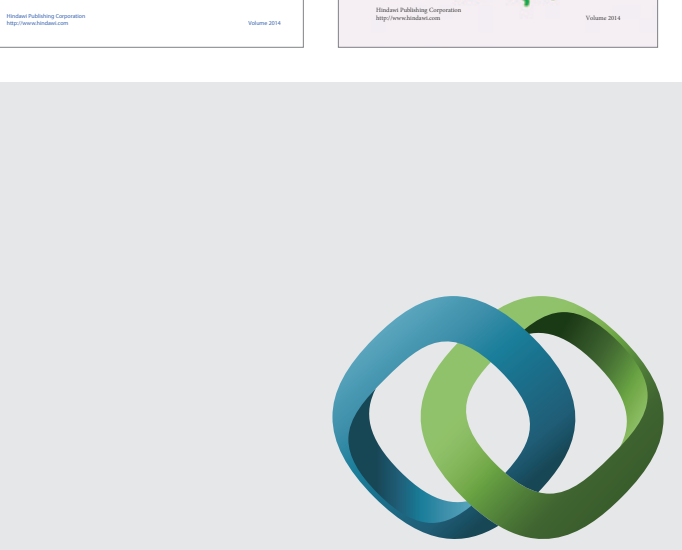

\section{Hindawi}

Submit your manuscripts at

http://www.hindawi.com
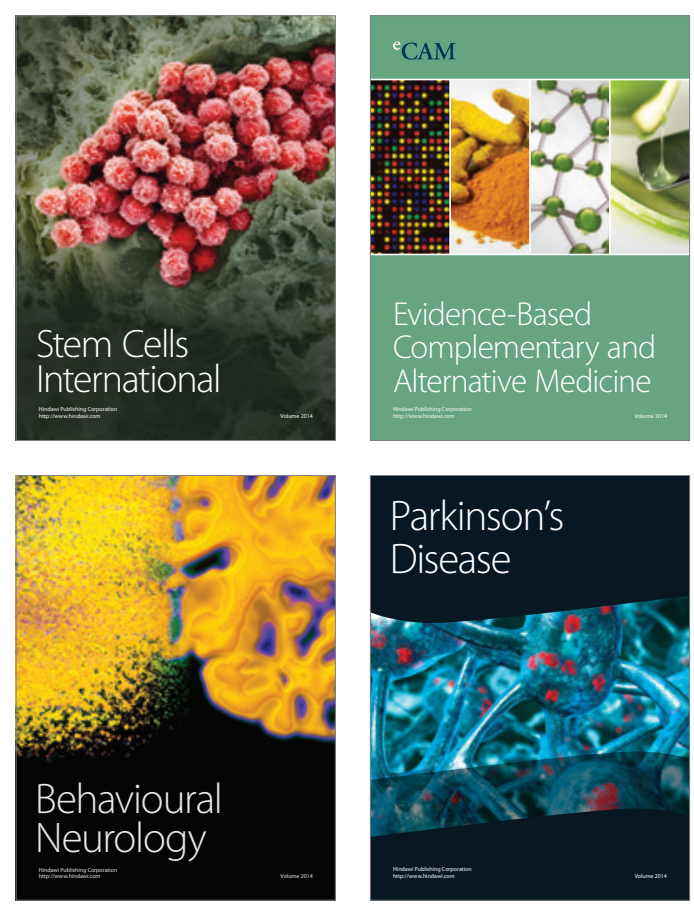

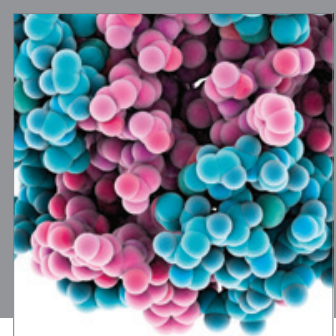

Journal of
Diabetes Research

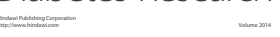

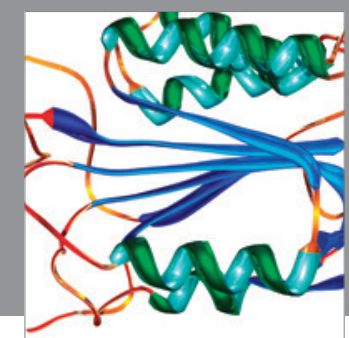

Disease Markers
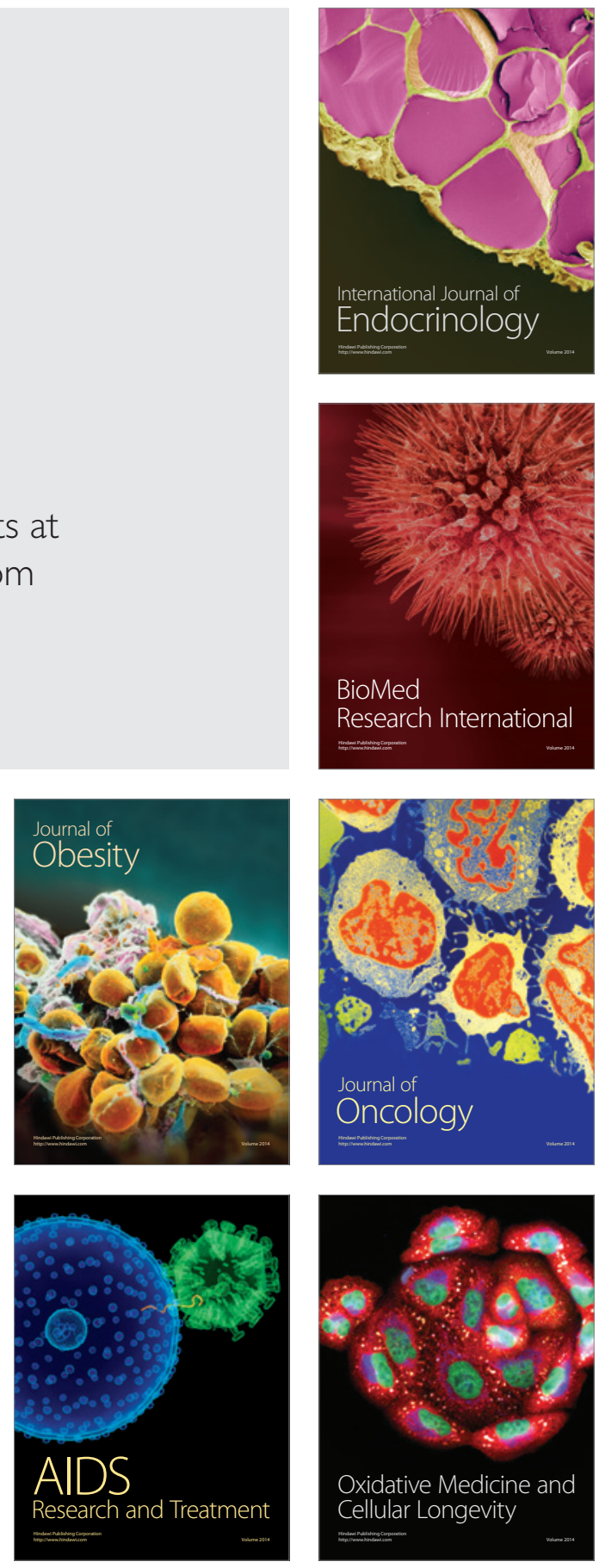